\title{
FACTOR ANALYSIS OF INTERFACE PROBLEMS AMONG CONSTRUCTION PARTIES - A CASE STUDY OF MRT
}

Rong-Yau Huang

Professor and Chairman, Institute of Construction Engineering and Management, National Central University, Chung-li, Taiwan., rhuang@cc.ncu.edu.tw

Chin-Tien Huang

Professor and Chairman, Institute of Construction Engineering and Management, National Central University, Chung-li, Taiwan., e0030006@ms38.hinet.net

Hung Lin

Candidate PH.D, Institute of Business Administration, National Cheng-Chi University

Wen-Hsiang Ku

Toshiba Information, Industrial and Power Systems Taiwan Corporation

Follow this and additional works at: https://jmstt.ntou.edu.tw/journal

Part of the Business Commons, and the Transportation Engineering Commons

\section{Recommended Citation}

Huang, Rong-Yau; Huang, Chin-Tien; Lin, Hung; and Ku, Wen-Hsiang (2008) "FACTOR ANALYSIS OF INTERFACE PROBLEMS AMONG CONSTRUCTION PARTIES - A CASE STUDY OF MRT," Journal of Marine Science and Technology. Vol. 16: Iss. 1, Article 7.

DOI: 10.51400/2709-6998.1997

Available at: https://jmstt.ntou.edu.tw/journal/vol16/iss1/7

This Research Article is brought to you for free and open access by Journal of Marine Science and Technology. It has been accepted for inclusion in Journal of Marine Science and Technology by an authorized editor of Journal of Marine Science and Technology. 


\title{
FACTOR ANALYSIS OF INTERFACE PROBLEMS AMONG CONSTRUCTION PARTIES -A CASE STUDY OF MRT
}

\author{
Rong-Yau Huang*, Chin-Tien Huang ${ }^{*}$, Hung Lin ${ }^{* *}$, and Wen-Hsiang $\mathrm{Ku}^{* * *}$
}

Key words : interface, factor analysis, configuration management, partnering.

\begin{abstract}
With the rapid development of technology and the increasingly bigger size of constructions, the involved parties are required to pay more attention to all types of difficult interface problems than ever before. By considering the mass rapid transit system (MRTS) as an example, several problems resulting from complicated mechanical, electrical, civil, and track interfaces led to enormously extra losses in the construction process. Accordingly, this paper intends to use quantitative methods to categorize a variety of interface problems in the MRTS construction projects as well as identify their individual impacts in order to clarify these interface problems. The analysis results identify six dimensions in the interface problems, among which the experience and coordination dimensions are crucial in terms of progress rate and quality. With a view of enhancing the efficiency and effectiveness of future projects, two feasible suggestions based on the results of this study are provided for all practitioners who are engaged in dealing with these broad and complicated interface problems.
\end{abstract}

\section{INTRODUCTION}

A construction project involves so many parties, such as owners, designers, construction contractors, subcontractors, maintenance contractors, and material suppliers, that some interface problems can arise, for example, the lack of cooperation, limited trust, and ineffective communication leading to an adversarial relationship among all these project stakeholders. This kind of relationship induces project delays, difficulty in resolving claims, cost overruns, litigations, and compromise project quality (Moore et al. [22]). On facing such types of situations, practitioners can only manage to re-

Paper submitted 11/22/06; accepted 07/19/07. Author for correspondence: Chin-Tien Huang e-mail: $0030006 @ m s 38 . h i n e t . n e t$

* Professor and Chairman, Institute of Construction Engineering and Management, National Central University, Chung-li, Taiwan. E-mail: rhuang@cc.ncu.edu.tw

**Candidate PH.D, Institute of Business Administration, National Cheng-Chi University

*** Toshiba Information, Industrial and Power Systems Taiwan Corporation solve them according to their own intuition instead of standards and thus the individual cannot be provided with a comprehensive picture of the interface problems. Consequently, these interface problems need to be immediately and carefully resolved, particularly through proper coordination, cooperation, and communication among the construction parties. Many studies listed in the literature discuss the interface problems between two parties, including designers and contractors (Al-Hammand and Assaf [6]; Al-Mansauri [7]), contractors and subcontractors (Al-Hammand [2], Hinze and Andres [15]), owners and maintenance contractors (Al-Hammand [3]), owners and designers (Al-Hammand, A and Al-Hammand, I [4]), as well as common interface problems among various construction parties (Al-Hammand [5]). However, all the main interface problems are identified only through a review of the literature and a pilot study of the interviews rather than by using any statistical tools. Moreover, the adverse effects of these interface problems among the related parties upon the completion and quality of the construction projects is not highlighted (Al-Hammand [5]). Therefore, it is essential to rigorously categorize the interface problems among various parties and accurately study their effects on the projects in order to avoid excessive costs as well as improve the quality of the construction projects.

In order to successfully combine practice and theory, this paper aims to identify the main interface problems among various construction parties and assess their impacts with particular reference to the mass rapid transit system (MRTS) in Taipei.

As far as the construction of the Taipei MRTS is concerned, the additional expenses incurred by the interface problems are higher than any other construction project owing to its highly complicated integration between the mechanical, electrical, civil, and track interfaces. As a result, the problems in the MRTS require greater consideration than any other type of construction. By using literature reviews, in-depth interviews, and survey questionnaires to identify the items in an empirical questionnaire, this study is used to analyze the responses by means of factor analysis and multiple regression analyses to categorize the interface problems among the parties as well as evaluate their own impacts on the project performance. For the sake of preventing possible mistakes induced by the individually different perceptions of the interface problems, all the respondents are remarkable experts in track projects. Finally, 
feasible solutions will be presented according to the results of this study in the hope of improving the future performance of similar construction projects.

\section{RSEARCH METHODOLOGY}

For this research, the undertaken methodology comprises several parts, including literature review, face-to-face interviews, and empirical questionnaire, which are similar to those in the paper by Walker [30]. Firstly, after a careful literature review and examination of interview results, an empirical questionnaire was developed and then it was sent to the respondents with eminent experience in the field, such as owners, design companies, contractors, and subcontractors. The questionnaire measured the respondents' attitudes and opinions according to the Likert scale and inquired about their personal information using open questions. According to their responses, factor analysis and multiple regression analyses were adopted to categorize these interface problems as well as identify their individual impact on the performance.

\section{LITERATURE REVIEW}

\section{Definition of Interface}

Previous researches have no consensus on the definition of interfaces, for example, Wang [31], Ye [33], and $\mathrm{Ku}$ [16] define an interface as a dimension between two firms or organizations that can mutually influence each other, whereas Lin [19], Pe [27], and $\mathrm{Wu}$ [32] believe that interfaces exist within the occasions, processes, systems, elements, and equipments. In any case, the concept of "the conflicts among units need to be coordinated and resolved" is generally accepted (Lai [17]). The units are likely to be contractors, materials, or events, and their interactive relationships are further prominent causes of interface problems. Therefore, the possibility of interface problems emerging would inevitably rise with the gradual development of construction projects together with an increasing complexity in the interactive relationships among the involved parties. With regard to the MRTS projects, interfaces would probably appear in electrical, civil, functional, physical, organizational, or contractual shapes (Li [18]). Hence, based on these previous researches, the definition of "the matters required to be physically and functionally coordinated or cooperated with among two or more subjects" is thought to be appropriate for this research.

\section{The Analysis of Construction Interface Management}

According to our definition of interface, a range of interfaces would come into existence between or among various parties in all types of construction projects. Hence, the importance of interface management is discussed as well as emphasized in literature. For instance, Stuckenbruck [28] suggested that one project involving numerous people, parties, and units must be carefully and effectively integrated into a single unit if it aims to operate smoothly so as to prevent incurring extra costs. Moreover, Chan et al. [10] proposed that a project could prosper only through the proper management of communication, coordination, and responsibility across a common

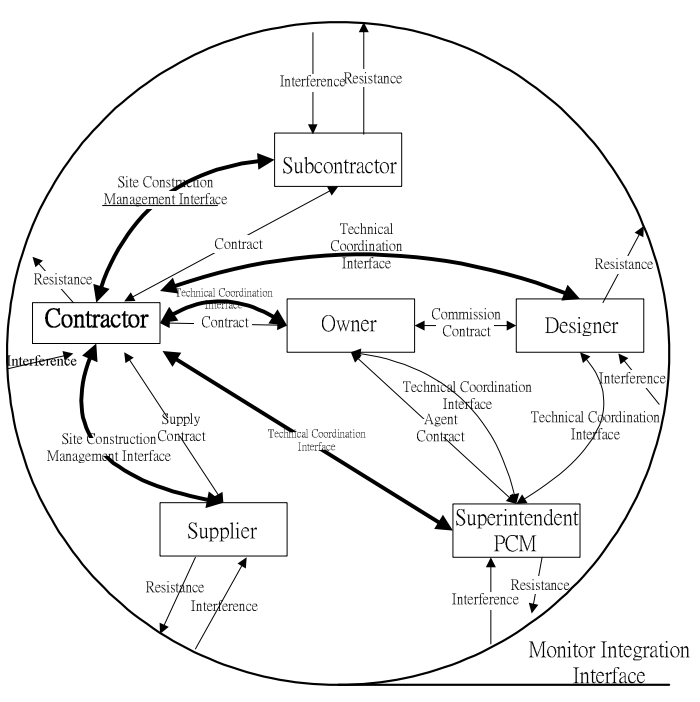

Fig. 1. Execution of Construction Interface Source: Ku (2000).

boundary between two organizations, phases, and independent physical entities. The critical relationship between interface management and project success is developed so constantly in literature (Morris [23], Stuckenbruck [28], Lock [20], Patrick [25], Delmon [13], Pavitt and Gibb [26]) that Morris [23] and Stuckenbruck [28] further proposed that the performance of interface management completely depended on how smooth the interface could be made. Therefore, it is evident that effective interface management and well-organized solution to interface problems would be essential for ensuring project success.

$\mathrm{Ku}$ [16] proposed five different perspectives in order to analyze interface management, namely, "contract interface", "technology interface", "monitor interface", "execution integration interface", and "the interacting behavior in the interface". Among all these views, the "execution integration interface" is the most practical and comprehensive to understand interface management involved in construction projects. Generally speaking, a construction project involves a variety of parties having contracts with each other, such as designers, PCM, constructors, suppliers, and executives in a project; however, only the major contractor possesses the authority to integrate and monitor the execution process (See Fig. 1). As a result, successful interface management in a construction project should carefully integrate all the technical and managerial matters among the involved parties and emphasize their coordination and cooperation. Otherwise, counteractions will emerge in the interface and cause damages to all the participants in the project.

\section{The Categories of Construction Interface Problems}

Many researches have examined the categories of interface problems in addition to investigating the criticality of the interface. For example, Stuckenbruck [28] sorted such interfaces into personal, organizational, and systematic ones, whereas Pavitt and Gibb [26] categorized them into physical, contractual, and organizational ones. On the contrary, some studies 
focused on common interface problems between any two construction parties, such as owners and contractors (Al-Hammand [1]), designers and contractors (Al-Hammand and Assaf [6], Al-Mansauri [7]), contractors and subcontractors (Al-Hammand [2], Hinze and Andres [15]), owners and maintenance contractors (Al-Hammand [3]), as well as among construction parties (Al-Hammand [5]). Furthermore, all of these examined interface problems were categorized into various types by authors' subjective judgments, including inadequate contract and specification, financial problems, environmental problems, and other problems. Nevertheless, all of the above interface problems fall under general management problems, which may not totally conform to the scope we intend to discuss in this research. Therefore, other peculiar but important interface problems in MRTS, which are not investigated in literature, should be taken into consideration due to the subject this paper discusses.

For a greater comprehensive understanding of the interface problems in TRMT, several face-to-face interviews and a short survey were conducted to procure other prominent interface problems possibly occurring in the TRMT construction project but not mentioned above. Most interviewees who are well-known experts or practitioners in track engineering provide extremely precious feedback and advice such that further subjects could be added to our research. According to their opinions, the three most talked about unique aspects, namely, cultural difference, technological improvement, and track characteristics, are likely to bring about deterioration in the project performance in the MRTS construction in Taiwan. The detailed components of each unique characteristic are listed as follows.

\section{1) Technological improvement}

\section{A. Limited personal experience and defective feedback}

Since the technological characteristics of track engineering changes with time, personal past experience about interface problems cannot be utilized in new projects. Therefore, previous solutions for interface problems might not be applicable for the present situation, which could bring about the occurrence of new interface problems.

\section{B. Increase in the uncertainty and ambiguity of interface conflicts}

With the emergence of new types of construction projects, unprecedented interface problems occur and thus create a great deal of uncertainty and ambiguity, which may raise the possibility of interface arguments and conflicts among the participating parties.

\section{Emergence of new techniques and new materials}

The emergence of novel products and materials due to uninterrupted research and development would upgrade the construction techniques. Because of the lack of knowledge about new techniques and materials, new problems are more likely to occur in construction projects.

\section{Incompetence in solving new technical problems}

Newly developed techniques have surpassed traditional imagination and thus the relevant staffs are incompetent in dealing with arguments arising from the development of new techniques. It is imperative to acquire more understanding of the new technical (know-how) problems in addition to personal past experiences. Otherwise, new types of interface problems will probably cause a huge disaster in construction projects.

\section{2) Track characteristics}

\section{A. Difficulty in coordination between interfaces}

Track engineering constructors do not embark on detailed design until they award the contract, which is different from other types of constructions. Thus, they try to use as much of their stock material as possible while undertaking the design. However, old-fashioned stock material does not meet the owner's requirement; therefore, it will result in poor interface coordination and bring about new interface problems.

\section{B. Parties' different opinions on mutual views and needs}

There are too many parties involved in a track engineering construction project to have a good understanding of mutual standpoints and needs among all the parties. If some party strongly insists on their own view, there will be competition and arguments within the interface and thus the entire project will get deferred.

\section{3) Cultural differences}

\section{A. Self-interest perspective}

In the Chinese society, the involved parties are likely to make decisions resulting in their own benefits instead of the benefit of the whole. Namely, they will think from the micro perspective, regardless of the possible loss to others and the entire project.

\section{B. Lack of a system updating new information}

The exchange of information among interfaces is the key factor in construction projects. Without an appropriate management system that undertakes updating experiences, there will not be any suitable reference for making future decisions.

Based on the previous description, 9 interface problems were subsequently adopted into the empirical questionnaire except for the original 19 interface problems in Al-Hammand's research [5]. Therefore, there are a total of 28 interface problems developed in this questionnaire. Moreover, certain interface problems defined by Al-Hammand [5] have to be slightly amended because of the different subject of this research. These problems in need of revision are "violating conditions of the contract" converted to "inconsistent planning", "poor quality of work" transformed to "insufficient negotiation", and "unfamiliarity with local laws of related governmental agencies" changed to "unfamiliarity with government audit system" and "unfamiliarity with local laws and regulations". A comparison between the interface problems discussed in this research and those discussed in Al-Hammand's study [5] is listed in Table 1. 
Table 1. The comparison of interface problems between Al-Hammad (2000) and this research.

\begin{tabular}{|c|c|c|}
\hline Al-Hammad (19 items) & Interface problem & This research (28 items) \\
\hline $\begin{array}{l}\text { Delay in progress payment by owner } \\
\text { Accuracy of the project cost estimate } \\
\text { Owner's low budget for construction rela- } \\
\text { tive to requirements } \\
\text { Price changes of materials and laborers } \\
\text { during construction }\end{array}$ & Financial problems & $\begin{array}{l}\text { Delay in progress payment by owner } \\
\text { Accuracy of the project cost estimate } \\
\text { Owner's low budget for construction relative to requirements } \\
\text { Price changes of materials and laborers during construction }\end{array}$ \\
\hline $\begin{array}{l}\text { Insufficient working drawing details } \\
\text { Insufficient specifications } \\
\text { Poorly written contract } \\
\text { Change order } \\
\text { Violating conditions of the contract }\end{array}$ & $\begin{array}{l}\text { Inadequate Con- } \\
\text { tract and Specifi- } \\
\text { cation }\end{array}$ & $\begin{array}{l}\text { Insufficient working drawing details } \\
\text { Insufficient specifications } \\
\text { Poorly written contract } \\
\text { Change order } \\
\text { Inconsistent planning }\end{array}$ \\
\hline $\begin{array}{l}\text { Weather conditions } \\
\text { Geological problems on site }\end{array}$ & $\begin{array}{l}\text { Environmental } \\
\text { Problems }\end{array}$ & $\begin{array}{l}\text { Weather conditions } \\
\text { Geological problems on site }\end{array}$ \\
\hline $\begin{array}{l}\text { Lack of communication between the con- } \\
\text { struction parties } \\
\text { Slowness of the owner in decision making } \\
\text { Delay in completion of the project } \\
\text { Lack of management supervision } \\
\text { Skills and productivity of laborers } \\
\text { Poor planning and scheduling } \\
\text { Poor quality of work } \\
\text { Unfamiliarity with local laws of related } \\
\text { governmental agencies }\end{array}$ & $\begin{array}{l}\text { Other Common } \\
\text { Interface Problems }\end{array}$ & $\begin{array}{l}\text { Lack of communication between the construction parties } \\
\text { Slowness of the owner in decision making } \\
\text { Delay in completion of the project } \\
\text { Lack of management supervision } \\
\text { Skills and productivity of laborers } \\
\text { Poor planning and scheduling } \\
\text { Insufficient negotiation } \\
\text { Unfamiliarity with government audit system } \\
\text { Unfamiliarity with local laws and regulations }\end{array}$ \\
\hline None & $\begin{array}{l}\text { Technological im- } \\
\text { provement }\end{array}$ & $\begin{array}{l}\text { Limited personal experience and defective feedback } \\
\text { Increase of the uncertainty and ambiguity of interface con- } \\
\text { flict } \\
\text { Emergency of new techniques and new materials } \\
\text { Incompetence for solving new technical problems }\end{array}$ \\
\hline None & $\begin{array}{l}\text { Track characteris- } \\
\text { tics }\end{array}$ & $\begin{array}{l}\text { Hardship of coordination between interfaces } \\
\text { Parties' different opinions on mutual views and needs }\end{array}$ \\
\hline None & Cultural difference & $\begin{array}{l}\text { Self-interest perspective } \\
\text { Lack of a system updating new information }\end{array}$ \\
\hline
\end{tabular}

\section{STUDY SURVEY}

\section{Empirical Questionnaire}

According to personal perceptions and hands-on experience, the respondents were requested to evaluate the severity of 28 interface problems in the MRTS and 2 project performances by means of a seven-point Likert scale $(1=$ strongly disagree and $7=$ strongly agree). All of the respondents are practitioners possessing eminent experience in the field and consensus about the definition of interface problems, including senior management representatives, senior engineers, consultants, and contractor and subcontractor organizations.

After the reduction of invalid replications, a total of 59 valid responses were obtained for analysis, and the overall response rate was approximately $60 \%$. These returned questionnaires consisted of 22 respondents from owners, 16 from design companies, and 21 from contractors. Two respondents had $\mathrm{PhD}$ degrees, while 27 had their master's degree. The remaining 17 respondents held bachelor's degrees in related fields. With regard to track construction engineering experiences, all of the respondents possessed related experiences but at disparate levels, that is, there were 47 respondents having more than 15 years of experience, 11 with 10-15 years of experience, and only 1 with less than 10 years of experience.

\section{Analysis of Survey Result}

Two statistical tools-factor analysis and multiple regression analysis-were used to analyze the data colleted from empirical questionnaires. The former was used to identify the underlying dimensions of the interface problems, whereas the latter was used to determine the factors with the strongest influence on the project performance. The analysis was conducted using the SAS software that provides a comprehensive range of statistical programs suitable for manipulating the work of the analysis. Prior to performing the factor analysis and multiple regression analyses, all the variables of the interface problems and the personal perceptions of the project performance were tested for potential outliers and normality. On the basis of the test results, was concluded that all the variables satisfied the basic assumptions of a linear regression model and were confirmed to be acceptable and reliable. 
Table 2. Summary of factor analysis (Management factor).

\begin{tabular}{|c|c|c|c|c|c|c|c|c|c|}
\hline \multirow[b]{2}{*}{ Problem } & \multirow[b]{2}{*}{$\begin{array}{c}\text { Explained } \\
\text { Proportion } \\
\%\end{array}$} & \multirow{2}{*}{$\begin{array}{l}\text { Cumula- } \\
\text { tive } \\
\text { Ex- } \\
\text { plained } \\
\text { Propor- } \\
\text { tion \% }\end{array}$} & \multicolumn{7}{|c|}{ Component factor } \\
\hline & & & $\begin{array}{l}\text { Mgt. } \\
\text { factor }\end{array}$ & $\begin{array}{l}\text { Exp. } \\
\text { factor }\end{array}$ & $\begin{array}{l}\text { Coo. } \\
\text { factor }\end{array}$ & $\begin{array}{l}\text { Contr. } \\
\text { factor }\end{array}$ & $\begin{array}{l}\text { AOG } \\
\text { factor }\end{array}$ & $\begin{array}{l}\text { Reg. } \\
\text { factor }\end{array}$ & $\begin{array}{l}\text { Com } \\
\text { mu- } \\
\text { nity }\end{array}$ \\
\hline $\begin{array}{l}\text { 15.Lack of communication } \\
\text { between relevant parties }\end{array}$ & & & 0.833 & 0.375 & 0.289 & 0.309 & 0.255 & 0.209 & 0.708 \\
\hline $\begin{array}{l}\text { 16.Deferring deci- } \\
\text { sion-making by owner }\end{array}$ & & & 0.816 & 0.358 & 0.309 & 0.290 & 0.248 & 0.473 & 0.734 \\
\hline $\begin{array}{l}\text { 10.Lack of proper coordi- } \\
\text { nation }\end{array}$ & & & 0.746 & 0.124 & 0.247 & 0.278 & -0.260 & 0.295 & 0.795 \\
\hline $\begin{array}{l}\text { 22.Insufficient compatibil- } \\
\text { ities of detail design }\end{array}$ & 38.25 & 38.25 & 0.719 & 0.260 & 0.322 & 0.456 & 0.455 & 0.184 & 0.621 \\
\hline 21.Discordant project plan & & & 0.712 & 0.346 & 0.354 & 0.407 & 0.367 & 0.289 & 0.570 \\
\hline $\begin{array}{l}\text { 18.Bad skills and produc- } \\
\text { tivity of labors }\end{array}$ & & & 0.696 & 0.311 & 0.521 & 0.412 & 0.437 & -0.011 & 0.667 \\
\hline $\begin{array}{l}\text { 12.Delay in owner pay- } \\
\text { ment }\end{array}$ & & & 0.680 & 0.575 & 0.201 & 0.089 & 0.450 & 0.318 & 0.688 \\
\hline Eigenvalue & & & & 10.7 & & & & & \\
\hline
\end{tabular}

First of all, a factor analysis is a statistical technique used to identify a relatively small number of factors that can be used to represent the relationships among sets of many interrelated variables (Norusis [24]). It was conducted to reduce the 28 items (interface problems) into a small number of underlying factors. The extraction and rotation of the factors were performed to yield a small number of factors and obtain a clearer picture of what each factor represents.

Seven factors were determined using the Kaiser method (Fig. 2), which retained the extracted factors if the values were greater than 1. However, considering the small value of $\lambda-1.0229$ - and slight variance-3.65\%, the seventh factor was eliminated; therefore, only six factors were introduced into this study.

Table 2 to table 7 individually shows the components of the six remaining factors, and the name of each factor was also determined by the correlation coefficients between these extracted factors and their own constituent problems. The analysis indicated the names of the six extracted factors are "management factor", "experience factor", "coordination factor", "contract factor", "acts of god factor", and "regulation factor" respectively, all of which were properly separated under the evidence that the inter-factor correlation coefficients is pretty low (see Table 8).

Each factor consisted of its own component interface problems; therefore, they can be named according to the common characteristics of their specific problems. The following section will explain the main reasons behind the name of every factor.

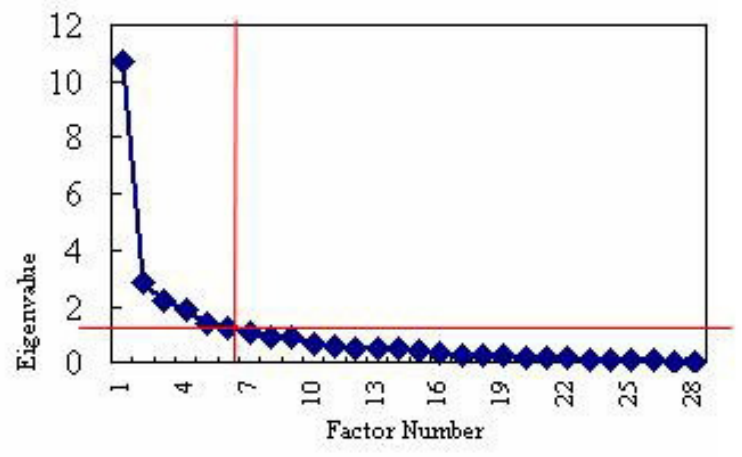

Fig. 2. Scree plot of 28 interface problems.

\section{1) Management factor}

It included different management problems, such as "lack of communication and coordination between relevant parties", "deferring decision-making by owner", "delay in owner payment", "bad decision-making timing", "insufficient compatibilities of detail design", "discordant project plan", etc. Based on these problems, as a result, the factor was named the "management factor".

\section{2) Experience factor}

This factor involved numerous problems regarding experience, such as "owner's high requirements but with a proportionally low budget", "poor accuracy of the project 
Table 3. Summary of factor analysis (Experience factor).

\begin{tabular}{|c|c|c|c|c|c|c|c|c|c|}
\hline \multirow[b]{2}{*}{ Problem } & \multirow{2}{*}{$\begin{array}{l}\text { Explained } \\
\text { Proportion } \\
\%\end{array}$} & \multirow{2}{*}{$\begin{array}{l}\text { Cumulative } \\
\text { Explained } \\
\text { Proportion } \\
\%\end{array}$} & \multicolumn{7}{|c|}{ Component factor } \\
\hline & & & $\begin{array}{l}\text { Mgt. } \\
\text { factor }\end{array}$ & $\begin{array}{l}\text { Exp. } \\
\text { factor }\end{array}$ & $\begin{array}{l}\text { Coo. } \\
\text { factor }\end{array}$ & $\begin{array}{l}\text { Contr. } \\
\text { r factor }\end{array}$ & $\begin{array}{l}\mathrm{AOG} \\
\text { factor }\end{array}$ & $\begin{array}{l}\text { Reg. } \\
\text { factor }\end{array}$ & Community \\
\hline $\begin{array}{l}\text { 4.Incompetence for solving } \\
\text { the problems of new tech- } \\
\text { niques }\end{array}$ & & & 0.323 & 0.918 & 0.311 & 0.057 & 0.312 & 0.313 & 0.857 \\
\hline $\begin{array}{l}\text { 3.Unpredictable issues } \\
\text { caused by new techniques } \\
\text { and new materials }\end{array}$ & & & 0.489 & 0.849 & 0.252 & 0.170 & 0.223 & 0.380 & 0.822 \\
\hline $\begin{array}{l}\text { 13.Accuracy of project } \\
\text { budget }\end{array}$ & & & 0.365 & 0.786 & 0.316 & 0.322 & 0.505 & 0.053 & 0.733 \\
\hline $\begin{array}{l}\text { 5.Contractors' designs don't } \\
\text { fit in with the owner's need }\end{array}$ & 10.06 & 48.31 & 0.301 & 0.715 & 0.611 & 0.104 & 0.277 & 0.099 & 0.693 \\
\hline $\begin{array}{l}\text { 14.Owner's high require- } \\
\text { ment but with proportionally } \\
\text { low budget }\end{array}$ & & & 0.569 & 0.657 & 0.327 & 0.412 & 0.586 & 0.360 & 0.724 \\
\hline $\begin{array}{l}\text { 1.Limited personal experi- } \\
\text { ence and poor data feedback }\end{array}$ & & & 0.152 & 0.646 & 0.444 & -0.052 & 0.276 & 0.604 & 0.757 \\
\hline $\begin{array}{l}\text { 2.Increase of the uncertainty } \\
\text { and ambiguity of interface }\end{array}$ & & & 0.465 & 0.625 & 0.618 & 0.187 & 0.388 & 0.322 & 0.633 \\
\hline Eigenvalue & 2.8172 & & & & & & & & \\
\hline
\end{tabular}

Table 4. Summary of factor analysis (Coordination factor).

\begin{tabular}{|c|c|c|c|c|c|c|c|c|c|}
\hline \multirow[b]{2}{*}{ Problem } & \multirow{2}{*}{$\begin{array}{l}\text { Explained } \\
\text { Proportion } \\
\quad \%\end{array}$} & \multirow{2}{*}{$\begin{array}{l}\text { Cumulative } \\
\text { Explained } \\
\text { Proportion } \\
\%\end{array}$} & \multicolumn{7}{|c|}{ Component factor } \\
\hline & & & $\begin{array}{l}\text { Mgt. } \\
\text { factor }\end{array}$ & $\begin{array}{l}\text { Exp. } \\
\text { factor }\end{array}$ & $\begin{array}{l}\text { Coo. } \\
\text { factor }\end{array}$ & $\begin{array}{l}\text { Contr. } \\
\text { factor }\end{array}$ & $\begin{array}{l}\mathrm{AOG} \\
\text { factor }\end{array}$ & $\begin{array}{l}\text { Reg. } \\
\text { factor }\end{array}$ & $\begin{array}{l}\text { Community } \\
\end{array}$ \\
\hline $\begin{array}{l}\text { 6.Interface parties' insis- } \\
\text { tence on their own views }\end{array}$ & & & 0.262 & 0.389 & 0.825 & 0.146 & 0.369 & 0.201 & 0.737 \\
\hline $\begin{array}{l}\text { 8.Lack of management sys- } \\
\text { tem updating new informa- } \\
\text { tion }\end{array}$ & & & 0.292 & 0.212 & 0.788 & 0.309 & 0.188 & 0.193 & 0.642 \\
\hline $\begin{array}{l}\text { 7.No realization in the criti- } \\
\text { cal point of whole construc- } \\
\text { tion projects }\end{array}$ & 7.85 & 56.16 & 0.279 & 0.335 & 0.761 & 0.086 & 0.102 & 0.181 & 0.639 \\
\hline $\begin{array}{l}\text { 19.Poor planning and } \\
\text { scheduling }\end{array}$ & & & 0.707 & 0.382 & 0.711 & 0.403 & 0.353 & -0.015 & 0.806 \\
\hline $\begin{array}{l}\text { 17. Contractors' insufficient } \\
\text { managerial abilities }\end{array}$ & & & 0.557 & 0.103 & 0.692 & 0.518 & 0.097 & 0.053 & 0.698 \\
\hline Eigenvalue & 2.1968 & & & & & & & & \\
\hline
\end{tabular}


Table 5. Summary of factor analysis (Contract factor).

\begin{tabular}{|c|c|c|c|c|c|c|c|c|c|}
\hline \multirow[b]{2}{*}{ Problem } & \multirow{2}{*}{$\begin{array}{l}\text { Explained } \\
\text { Proportion } \\
\quad \%\end{array}$} & \multirow{2}{*}{$\begin{array}{l}\text { Cumulative } \\
\text { Explained } \\
\text { Proportion } \\
\%\end{array}$} & \multicolumn{3}{|c|}{ Component factor } & \multirow[b]{2}{*}{$\begin{array}{l}\text { Contr. } \\
\text { factor }\end{array}$} & \multirow[b]{2}{*}{$\begin{array}{l}\mathrm{AOG} \\
\text { factor }\end{array}$} & \multirow[b]{2}{*}{$\begin{array}{l}\text { Reg. } \\
\text { factor }\end{array}$} & \multirow[b]{2}{*}{ Community } \\
\hline & & & $\begin{array}{l}\text { Mgt. } \\
\text { factor }\end{array}$ & $\begin{array}{l}\text { Exp. } \\
\text { factor }\end{array}$ & $\begin{array}{l}\text { Coo. } \\
\text { factor }\end{array}$ & & & & \\
\hline $\begin{array}{l}\text { 25.Unclear details in the } \\
\text { drawing }\end{array}$ & \multirow{4}{*}{6.82} & \multirow{4}{*}{62.98} & 0.341 & 0.140 & 0.216 & 0.893 & 0.101 & 0.026 & 0.836 \\
\hline 24.Incomplete contract & & & 0.499 & 0.013 & 0.131 & 0.844 & 0.136 & 0.197 & 0.813 \\
\hline 23.Design change & & & 0.396 & 0.313 & 0.445 & 0.645 & 0.415 & 0.156 & 0.549 \\
\hline $\begin{array}{l}\text { 9.Affected by external par- } \\
\text { ties }\end{array}$ & & & 0.441 & 0.091 & 0.527 & 0.541 & 0.216 & 0.539 & 0.706 \\
\hline Eigenvalue & 1.9103 & & & & & & & & \\
\hline
\end{tabular}

Table 6. Summary of factor analysis (Acts-of -God factor).

\begin{tabular}{|c|c|c|c|c|c|c|c|c|c|}
\hline \multirow[b]{2}{*}{ Problem } & \multirow{2}{*}{$\begin{array}{l}\text { Explained } \\
\text { Proportion } \\
\quad \%\end{array}$} & \multirow{2}{*}{$\begin{array}{l}\text { Cumulative } \\
\text { Explained } \\
\text { Proportion } \\
\%\end{array}$} & \multicolumn{3}{|c|}{ Component factor } & \multirow[b]{2}{*}{$\begin{array}{l}\text { Contr. } \\
\text { factor }\end{array}$} & \multirow[b]{2}{*}{$\begin{array}{l}\text { AOG } \\
\text { factor }\end{array}$} & \multirow[b]{2}{*}{$\begin{array}{l}\text { Reg. } \\
\text { factor }\end{array}$} & \multirow[b]{2}{*}{$\begin{array}{l}\text { Community } \\
\text { Com }\end{array}$} \\
\hline & & & $\begin{array}{l}\text { Mgt. } \\
\text { factor }\end{array}$ & $\begin{array}{l}\text { Exp. } \\
\text { factor }\end{array}$ & $\begin{array}{l}\text { Coo. } \\
\text { factor }\end{array}$ & & & & \\
\hline 27. Weather problems & & & 0.398 & 0.341 & 0.196 & 0.116 & 0.872 & 0.221 & 0.840 \\
\hline 28. Geological problems & 4.9 & 67.88 & 0.264 & 0.365 & 0.174 & 0.091 & 0.817 & 0.345 & 0.754 \\
\hline $\begin{array}{l}\text { 26. Rise of the material } \\
\text { price }\end{array}$ & & & 0.083 & 0.272 & 0.402 & 0.561 & 0.735 & -0.066 & 0.803 \\
\hline
\end{tabular}

Eigenvalue 1.371

Table 7. Summary of factor analysis (Regulation factor).

\begin{tabular}{|c|c|c|c|c|c|c|c|c|c|}
\hline \multirow[b]{2}{*}{ Problem } & \multirow{2}{*}{$\begin{array}{l}\text { Explained } \\
\text { Proportion } \\
\quad \%\end{array}$} & \multirow{2}{*}{$\begin{array}{l}\text { Cumulative } \\
\text { Explained } \\
\text { Proportion } \\
\%\end{array}$} & \multicolumn{3}{|c|}{ Component factor } & \multirow[b]{2}{*}{$\begin{array}{l}\text { Contr. } \\
\text { factor }\end{array}$} & \multirow[b]{2}{*}{$\begin{array}{l}\text { AOG } \\
\text { factor }\end{array}$} & \multirow[b]{2}{*}{$\begin{array}{l}\text { Reg. } \\
\text { factor }\end{array}$} & \multirow[b]{2}{*}{$\begin{array}{l}\text { Community } \\
\text { Comm }\end{array}$} \\
\hline & & & $\begin{array}{l}\text { Mgt. } \\
\text { factor }\end{array}$ & $\begin{array}{l}\text { Exp. } \\
\text { factor }\end{array}$ & $\begin{array}{l}\text { Coo. } \\
\text { factor }\end{array}$ & & & & \\
\hline $\begin{array}{l}\text { 11. Unfamiliarity with gov- } \\
\text { ernment audit system }\end{array}$ & \multirow{2}{*}{4.35} & \multirow{2}{*}{72.23} & 0.404 & 0.507 & 0.166 & 0.137 & 0.351 & 0.819 & 0.813 \\
\hline $\begin{array}{l}\text { 20. Unfamiliarity with local } \\
\text { laws and regulations }\end{array}$ & & & 0.500 & 0.271 & 0.439 & 0.341 & 0.430 & 0.548 & 0.587 \\
\hline Eigenvalue & 1.2184 & & & & & & & & \\
\hline
\end{tabular}

Table 8. Rotated inter-factor correlation.

\begin{tabular}{l|cccccc}
\hline Factor & Mgt. factor & Exp. factor Coo. factor & Contr. factor & AOG factor Reg. factor \\
\hline Mgt. factor & 1.0000 & & & & & \\
Exp. factor & 0.3332 & 1.0000 & & & & \\
Coo. factor & 0.3534 & 0.3208 & 1.0000 & & 1.0000 & \\
Contr. factor & 0.3930 & 0.0704 & 0.3181 & 0.2403 & 1.000 & \\
AOG factor & 0.2561 & 0.3980 & 0.2848 & 0.2400 & 1.0000 \\
Reg. factor & 0.2779 & 0.2372 & 0.1133 & 0.0260 & 0.1015 & \\
\hline
\end{tabular}




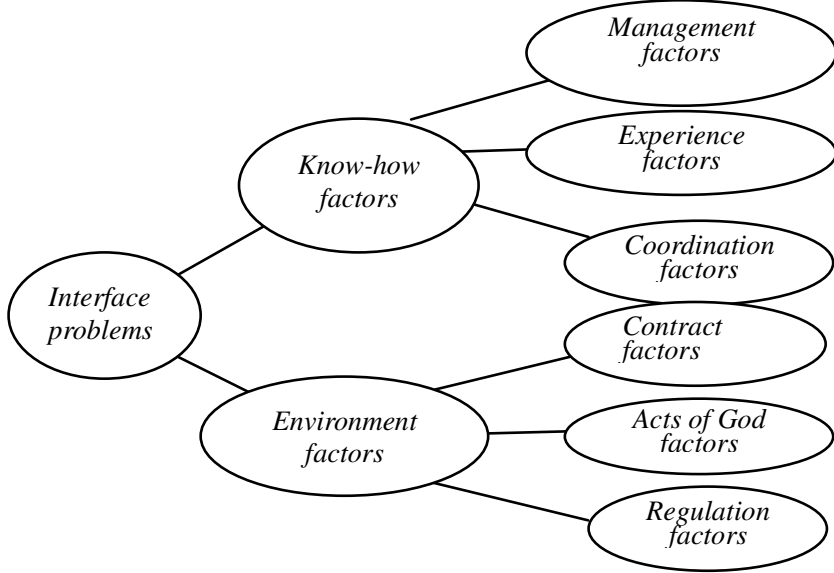

Fig. 3. Inter-relationship among interface problems. Source: arranged by this research.

budget", "contractors' designs do not fit in with the owner's need", "incompetence in solving the problems of new techniques", and so on. All of the interface problems are caused due to deficient experiences leading to poor flexibility in the adaptation to a new environment. As a result, the name "experience factor" was considered suitable.

\section{3) Coordination factor}

The third interface factor comprised some communication problems that might lead to serious inefficiency, such as "poor planning and scheduling" and "lack of a management system updating new information". Consequently, the name "coordination factor" was considered to be appropriate.

\section{4) Contract factor}

This factor consisted of several problems appearing in the contract execution, like "unclear details in the drawing", "incomplete contract", "design change", and so on. All these types of interface problems are considered to fall under the same category because they usually occur when the involved parties make or execute contracts. Therefore, the name "contract factor" was given to the fourth factor.

\section{5) Acts-of-Godfactor}

The fifth factor involved a few natural reasons, which cannot be controlled by human beings, for example, "weather problems", "geological problems", and "increase in the material price". Accordingly, the factor was called the "acts-of-God factor".

\section{6) Regulation factor}

The interface problems in this factor were caused by the unfamiliarity of the related parties with local rules, including local laws or regulations as well as the government audit system. Consequently, the name "regulation factor" was found to be appropriate.

In addition, the abovementioned interface problems can be further categorized. On one hand, the management, experience,
Table 9. Reliability test of interface problem factors.

\begin{tabular}{l|llllll}
\hline & Factor1 & Factor2 & Factor3 & Factor4 & Factor5 & Factor6 \\
\hline Factor & Manage- & & Coordi- & & & \\
Name & ment & Experience & $\begin{array}{l}\text { Cordion } \\
\text { nation }\end{array}$ & Contract & Act-of-god Regulation \\
& Factor & Factor & Factor & Factor & Factor \\
$\begin{array}{l}\text { Cron- } \\
\text { bach's } \alpha\end{array}$ & 0.836 & 0.842 & 0.857 & 0.844 & 0.826 & 0.760 \\
\hline
\end{tabular}

and coordination factors can be attributed to the lack of personal ability to deal with "know-how-related" problems and thus these factors are called the "know-how factor". On the other hand, the contract, acts-of-God, and regulation factors are caused owing to the poor adaptation of the parties to the sudden changes in national or foreign environments. Hence, these three factors can be grouped into the "environmental factor". Fig. 3 shows the relationship among the interface problems discussed in this research.

\section{Reliability}

Reliability is often used to evaluate the consistency or stability of the questions in the questionnaire in order to imply the reliability of the dimensions. The index "Cronbach's $\alpha$ " is commonly used to determine whether $\mathrm{K}$ questions are sufficiently reliable to represent a certain dimension. However, the square of the correlation coefficient $\left(P_{T, S}^{2}\right)$ between the dimension value $(\mathrm{T})$ and the summary of $\mathrm{K}$ questions $(\mathrm{S})$ can perform the same function as that of "Cronbach's $\alpha$ ". The formula can be explained by Equation (1).

$$
\begin{aligned}
& \text { Cronbach's } \alpha=\frac{[\operatorname{Cov}(T, S)]^{2}}{\operatorname{Var}(T) \operatorname{Var}(S)}=P_{T, S}^{2} \\
& =\frac{\left[\operatorname{Cov}\left(T, \sum_{k=1}^{k} X_{k}\right)\right]}{\operatorname{Var}(T) \operatorname{Var}(S)}=\frac{K}{K-1}\left[1-\frac{\sum_{k=1}^{k} \operatorname{Var}\left(X_{k}\right)}{\operatorname{Var}\left(\sum_{k=1}^{k} X_{k}\right)}\right]
\end{aligned}
$$

In this research, reliability analysis was utilized for two reasons. Firstly, in order to ensure the accuracy of the extracted factors, this index was used to test the reliability associated with each factor. As can be seen, most values were greater than 0.7 except for the regulation factor, which was 0.693 - only slightly lower than 0.7 (See Table 9). Consequently, it supported the reasons for its nomenclature as stated above.

With regard to the second section, $\alpha$ was taken as a preliminary work before the beginning of the multiple regression analysis because it can confirm if the dependent variables were reliable. With reference to the literature review (Cheng [11]) and face-to-face interview, "the rate of project progress" and "the quality of the project" were such critical indicators to assess the construction engineering project that they could represent the projects' performance. However, the constituent 
Table 10. Multiple regression results for rate of project progress.

\begin{tabular}{lcl}
\hline $\begin{array}{c}\text { Independent variable } \\
\text { (underlying success factor) }\end{array}$ & $\begin{array}{c}\text { Standard- } \\
\text { ized coeffi- } \\
\text { cient }(\beta)\end{array}$ & P value \\
\hline Experience factor (Factor 2) & 1.08002 & $0.0339^{* *}$ \\
Coordination factor (Factor 3) & 0.99676 & $0.0424^{* *}$ \\
Contract factor (Factor 4) & 0.65301 & 0.1802 \\
Management factor (Factor 1) & 0.00617 & 0.9904 \\
Regulation factor (Factor 6) & -0.4003 & 0.374 \\
Act-of-god factor (Factor 5) & -0.46157 & 0.337 \\
\hline
\end{tabular}

Samples $=59 ;$ Model $\mathrm{P}$ value $=0.0162 ; \mathrm{R}^{2}=0.25 ;$ Adjusted $\mathrm{R}^{2}=0.22$

Note $1: *$ means $\mathrm{p}$ value $<0.1 ; * *$ means $\mathrm{p}$ value $<0.05$

Note 2 : Dependent variable : rate of project progress

questions of each indicator were required to be testified before being adopted as the dimension of the construction project performance.

The analysis result clearly reveals that the $\alpha$ value of both these indicators were 0.789 and 0.866 , respectively-both far higher than the empirically critical value of 0.6 (Chow [12]); as a result, it proved that the questions were so reliable that they could represent the constructions they were supposed to belong to and their items can be reduced to denote the dimensions by average.

\section{Validity}

Validity indicates how valid the questionnaire is, and it is commonly used to measure the quality of the variable. Restrained by its subjectiveness, validity is determined only using personal logic. In this research, all the questions were established on theoretical foundation, empirical study, logical deduction, and expert consensus so that sufficient validity is verified. Moreover, it is proven to be valid through high correlation coefficients between the extracted variables and the component questions. Consequently, it was testified that all the questions in the questionnaire were valid.

\section{Multiple Regression Analysis}

Two multiple regression analyses were conducted between two different construction performances (rate of project progress and quality of project, respectively) as dependent variables and six underlying interface problem factors as independent variables. They were both carried out through the SAS REG program.

Table 10 shows the standardized regression coefficient $(\beta)$, coefficient determination $\left(\mathrm{R}^{2}\right)$, adjusted $\mathrm{R}$-square value (adjusted $\mathrm{R}^{2}$ ), and significance level ( $\mathrm{p}$ ) for the model that uses the "rate of project progress" as the dependent variable, whereas Table 11 shows these values in which the "quality of project" is used as the dependent variable. In other words, the multiple regression analyses could determine the interface
Table 11. Multiple regression results for quality of project.

\begin{tabular}{lcc}
\hline $\begin{array}{l}\text { Independent variable } \\
\text { (underlying success factor) }\end{array}$ & $\begin{array}{c}\text { Standardized } \\
\text { coefficient }(\beta)\end{array}$ & P value \\
\hline Coordination factor (Factor 3) & 1.34346 & $0.0027^{* *}$ \\
Experience factor (Factor 2) & 0.84771 & $0.06{ }^{*}$ \\
Contract factor (Factor 4) & 0.23935 & 0.5782 \\
Management factor (Factor 1) & -0.15252 & 0.7371 \\
Act-of-god factor (Factor 5) & -0.28743 & 0.5006 \\
Regulation factor (Factor 6) & -0.46188 & 0.2502 \\
\hline Sample=59; Model P value $=0.0061 ; \mathrm{R}^{2} 0.28 ;$ Adjusted $\mathrm{R}^{2}=0.20$ \\
\hline
\end{tabular}

Note $1: *$ means $\mathrm{p}$ value $<0.1 ; * *$ means $\mathrm{p}$ value $<0.05$

Note 2 : Dependent variable : quality of project

problem factor having a significant impact on the project performances.

As can been seen from Table 10, in the model with the "rate of project progress" as the dependent variable, $\mathrm{R}^{2}$ was 0.25 and adjusted $\mathrm{R}^{2}$ was 0.22 -both these values were greater than the lowest accepted standard of 0.18 (Flury and Riedwyl 1988). Altogether, $22 \%$ of the perception of the "rate of project progress" variance was explained by these six interface problem factors. Meanwhile, the overall p-value for this model was 0.0162 -much lower than 0.05 , which implied that different interface problems would have a significant influence on the rate of project progress. As far as the individual factors were concerned, the $\mathrm{p}$-values for the experience and coordination factors were 0.0339 and 0.0424 , respectively-both lower than 0.05; their standardized coefficients were 1.08002 and 0.99676 , both of which were positive. Therefore, it can be claimed that "the rate of project progress" would be positively influenced by these two interface problems, whereas it would not be influenced by other problems. The equation of the regression model of the "rate of project progress" as the dependent variable is described in Equation (2).

$$
\begin{gathered}
y_{n}=34.59322+0.00617 \chi_{1}+1.08002 \chi_{2}+0.99676 \chi_{3}+ \\
(<.0001 * *)(0.9904) \quad(0.0339 * *) \quad(0.0424 *) \\
+0.65301 \chi_{4}-0.46157 \chi_{5}-0.4003 \chi_{6}+\mathcal{E}_{n} \\
(0.1802) \quad(0.337) \quad(0.374)
\end{gathered}
$$

Moreover, Table 11 evinces some details about the model with the "quality of project" as the dependent variable in which $\mathrm{R}^{2}$ was 0.28 and adjusted $\mathrm{R}^{2}$ was 0.20 - both these values are higher than the lowest accepted standard of 0.18 (Flury and Riedwyl 1988). Totally, 20\% of the perception of the "quality of project" variance was accounted for by the six interface problem factors. The overall p-value was 0.0061 , which was markedly lower than 0.05 , which implied that the different interface problems would significantly influence the quality of the project. Although there were two similar sig- 
nificant interface problem factors in this model-"coordination factor" and "experience factor" with standardized coefficients (p-values) of $1.34346(0.0339)$ and $0.84771(0.0424)$, respectively, it is worth noting that the degree of impact was just opposite to that of the previous model. In other words, the "coordination factor" influenced "the quality of project" more than the "experience factor", while the "experience factor" affected "the rate of project progress" more than the "coordination factor". The equation of the regression model of the "quality of project" as the dependent variable is described in Equation (3).

$$
\begin{gathered}
y_{n}=29.62712-0.15252 \chi_{1}+0.84771 \chi_{2}+1.34346 \chi_{3}+ \\
(<.0001 * *) \quad(0.7371) \quad(0.06 *) \quad(0.0027 * *) \\
+0.23935 \chi_{4}-0.28743 \chi_{5}-0.46188 \chi_{6}+\mathcal{E}_{n} \\
(0.5782) \quad(0.5006) \quad(0.2502)
\end{gathered}
$$

The results of the multiple regression analyses indicate that the interface problems caused by the coordination and experience factors significantly influence the project's ultimate performances. It implies that "learning from experience" and "effectively integrating all interfaces" would be decisive causes for a project's success. Moore et al. [22] proposed that mutual goals, unwavering commitment, and support from all the levels of management are the essential elements in partnering projects. Meanwhile, proper coordination between the involved parties plays a more important instructive role in the identification of problems and the resolution of conflicts. Further, both these interface problems belong to the know-how dimension, so they can be resolved through cooperation and sharing. However, the premise of the solutions to these problems is to enhance the participants' identification and involvement to such an extent that they would be willing to share power and resources benefiting the overall organizational goals (Brooke and Litwin [9]).

Chan et al. [10] attempted to determine the critical factor in a construction project in the form of partnership and thus proposed that "willingness to share resources among project participants" and "establishment of conflict resolution strategy" were the first two critical factors for successful partnering projects. Despite the different perspectives obtained in our research, the conclusion is similar to some extent. The two critical factors for successful partnering projects are similar to those of the multiple regression analyses used in this research because the experience factor is a crucial resource that needs to be shared in order to facilitate the project, while the coordination factor could reduce the arguments caused because of interest conflicts.

Last but not the least, as indicated by the regression results, the "coordination factor" has a greater impact on the "quality of project" but lesser influence on the "rate of project progress" in comparison to the "experience factor". Therefore, the "experience factor" mainly dominated the "rate of progress factor", while the "coordination factor" was chiefly concerned with the "quality of project factor". Nevertheless, with regard to the overall impacts, experience is only a reference for deci- sion, while coordination is an antecedent task; therefore, the latter is much more vital in construction projects.

\section{SUGGESTIONS FOR THE CRITICAL INTERFACE PROLBEMS}

According to the results, two important interface problems should be noticed and monitored such that the precious resources in the organization can be effectively and efficiently utilized. For the purpose of reducing the harm that they could cause and improving future performance, two solutionsproject partnering and configuration management—have been proposed as follows.

\section{Project Partnering}

Partnering is such a magnificent technique that it can create an effective project management process between two or more organizations along with avoiding the repetitive occurrence of problems and possible litigation in the construction project. It intends to generate an organizational environment of trust, open communication circumstances, and employees' involvement. In terms of the definition presented by the American Construction Industry Institution (ACII), project partnering is the "long-term commitment between two or more organizations for the purpose of achieving specific business objectives by maximizing the effectiveness of each participant's resources". Consequently, it might help the construction project proceed more smoothly without the interference of the interface problems, particularly the coordination and experience factors, because this could lead to participants' dedication to common goals, their understanding of mutual expectations and values, and an entirely harmonic and cooperative atmosphere.

Chan et al. [10] illustrated that project partnering has been gradually applied in the construction industries in the Asian regions, such as Hong Kong, over the recent years, although it has been developed in the United States and popular in the United States and United Kingdom. For the sake of its effectiveness in future construction projects in Taiwan, the solution to these major interface problems with a significant influence should be taken into consideration before any future construction project is launched.

\section{Configuration Management}

Configuration management is a management discipline as well as a process: its purpose is really quite simple and elegant. It is designed to ensure that organizations possess the information they need to guarantee that the expected performance is met. Moreover, configuration management can provide a method and program for the management of change orders. In the long term, it can prevent unnecessary changes from taking place as well.

The idea of configuration management is helpful for the settlement of confrontations when inconsistencies occur between subsequent performances and the original plan and design. Therefore, numerous interface problems caused by poor coordination can be effectively reduced because it can setup a standard for the parties to abide by. Further, the configuration 
management program can effectively manage the process of change orders and feedback-related information to future plans or specification designs in order to avoid the repetition of the same interface problems. For example, the so-called plan-do-check-act (PDCA) model, which utilizes the method of identification, control, audit, and status accounting, can provide an effective interface management model to facilitate the smooth working of the project. Therefore, the experience of handling interface problems in a construction project can be reserved, and the cost of cooperation and coordination can diminish as well

\section{Potential Benefits of Partnering and Configuration Management}

There are two main reasons why partnering and configuration management should be practically applied in a construction project: (1) by using these parameters, all participants can possess a lucid understanding of earlier interface conflicts such that uncertainty can be avoided and management cost can be reduced and (2) a win-win situation can be achieved by means of the mutual cooperation between all the parties on the basis of partnering. In particular, Love [21] indicated the benefits of partnering between contractors and subcontractors, including higher productivity, better communication, unselfish resource sharing, and less arguments about the project's progress. As a result, these two tools can deal with the problems caused particularly by poor communication. Despite the increase in the number of personnel or training cost, the benefits of these models are remarkably high than the expenses associated with them, because they can reduce the possibility of interface problems with high-variable costs..

\section{CONCLUSIONS AND SUGGESTIONS}

\section{Conclusions}

This research initiated a comprehensive investigation through face-to-face interviews and questionnaires to categorize common interface problems in the MRTS and discussed the relationship between them and the project performance. It provides an overview of foreign studies in terms of significant interface problems in track engineering projects. The research findings were confirmed to be applicable and influential to the majority of future track engineering projects.

1. Six interface problems were extracted by using a factor analysis involving 28 variables developed through a synthesis of previous surveys and opinions from industry practitioners on track engineering projects, namely, management factor, experience factor, coordination factor, contract factor, acts-of-God factor, and regulation factor.

2. On one side, two interface problems (experience and coordination factors) were identified to be critical with regard to project performance. They both occurred due to the lack of know-how. On the other hand, in spite of the insignificance of the remaining four factors, they make the overview of interface problems more complete. Therefore, in practice, the first step to solve interface problems is to train employees, increase their coherence, and create an atmosphere of cooperation.

3. Past experience dominates the rate of project progress and thus experience and instruction should be emphasized among the involved parties. With regard to practical application, it is crucial to avoid the repetition of the same mistakes and thus some taskforces comprising experienced personnel should be formed, whereas inexperienced employees should get involved in the construction project. For example, configuration management, maintaining the requisite designs, and earlier solutions to interface problems can efficiently lower wastage with regard to cost and time [8].

4. Coordination is so critical to the quality of the project that a system that is capable of facilitating the participants' knowledge of their mutual needs should be established to avoid internal competition for resources. Integration will be the core ingredient of management in the future as well as the essential part of tomorrow's organization; therefore, to increase competitiveness, it becomes vital to establish the integral platforms for proper coordination among the participants.

5. Environmental factors seem insignificant to the project performance because they are external forces that are not brought about by humans. As a result, the importance of the environment should be less than that of humans in the entire construction project. Two solutions to the main interface problems among human factors-project partnering and configuration management-are presented in this article with the expectation to improve the effectiveness and efficiency in future construction projects.

\section{Suggestions}

1. According to the results obtained from this research, there is no significant influence of environmental factors on the construction performance. Nevertheless, in practice, construction performances are apparently restrained by local regulations and global market integration. As a result, an investigation of the relationship between environmental factors alone and the construction performance should be conducted in the future.

2. A series of in-depth cases on various track engineering construction projects, such as Kaohsiung MRTS or Taiwan High-Speed Rail Project, should be launched to verify the applicability and reliability of the consequences indicated in this research. The industry with the best practice can be denoted as the benchmark for similar construction projects in the future and effective strategies can also be suggested to enhance the project performance and improve the dispute resolution mechanisms.

3. Long-term observations with the establishment of database in the future are beneficial for a comprehensive understanding of a range of interface problems, which are not completely revealed in this study. By means of a full-scale survey, the possible problems can be understood and controlled on a pre-contract basis and thus the standard of track engineering construction can be effectively enhanced.

\section{REFERENCE}

1. Al-Hammad, A., "A Study of The Interface Problems between Owners and Contractors over the Construction of Residential Housed in Saudi Arabia," Housing Sci., Vol. 14, No. 4, pp. 245-257 (1990).

2. Al-Hammad, A., "Factors Affecting the Relationship between Contractors 
and Ttheir Sub-Contractors in Saudi Arabia," J. Perf. Constr. Fac. ASCE, Vol. 21, No. 5, pp.194-205 (1993).

3. Al-Hammad, A., "Interface Problems between Owners and Maintenance Contractors in Saudi Arabia," J. Perf. Constr. Fac. ASCE, Vol. 9, No. 3, pp.194-205 (1995).

4. Al-Hammad, A., and Al-Hammad, I., "Interface Problems between Building Owners Designers," J. Perf. Constr. Fac., ASCE, Vol. 10, No. 3 , pp.123-126 (1996).

5. Al-Hammad, A., "Common Interface Problems Among Various Construction Parties," J. Perf. Constr. Fac. ASCE, pp. 71-74 (2000).

6. Al-Hammad, A., and Assaf, S., "Design-Construction Interface Problems in Saudi Arabia," Building Res. and Info., Vol. 21, No. 1, pp.60-63 (1992).

7. Al-Mansouri, O., "The Relationship between the Designer and the Contractor in Saudi Arabia," PhD thesis, University of Reading, Reading, U.K (1988).

8. Boznak, R. G., "Configuration Management- The Next Engineering Management Revolution", Managing Technology in a Competitive Environment: 2nd International Conference on Engineering Management, IEEE TORONTO, pp. 207-210 (1989)

9. Brooke, K. L and Litwin, G. H., "Mobilizing the Partnering Process", Journal of Management in Engineering, ASCE, Vol. 13, No. 4, pp. $42-48$ (1997).

10. Chan, A. P. C., Chan, D. W. M., Chiang, Y. H., Tang, B. S., Chan, E. H. W. and Ho, K. S. K., "Exploring Critical Success Factors for Partnering in Construction Projects," J. Constr. Eng. Manage., ASCE, pp. 188-198 (2004).

11. Cheng, S. H. "A Study on the Mechanism of the Assessment on Construction Companies during the Public Project Construction Period" Master Thesis, Chung Hua University, Taipei (2004)

12. Chow, W. S., "Multivariate Statistical Analysis," Best-Wise Publishing Co. LTD. Taipei, pp. 632-642 (2002)

13. Delmon, J., BOO/BOT Projects: A commercial and Contractual Guide, Sweet \& Maxwell, London (2000).

14. Flury, B. and Riedwyl, H. "Multivariate Statistics, A Practical Approach." Cambridge University Press (1988).

15. Hinze, J., and Andres, T., "The Contractor-Subcontractor Relationship: The Subcontractor's View," J. Constr. Engrg. and Mgmt., ASCE, Vol. 120 No. 2, pp. 274-287 (1994).

16. Ku, W. H. "A Study of Establishing Lessons-Learned Database for Contractor," Master Thesis, National Taiwan University (2000).

17. Lai, M. L., "Application of Construction Interface Management," Master
Thesis, National Chiao Tung University (2005).

18. Li, C. A., "Interface Management and Coordination," interior annual research paper about construction engineering, Department of Rapid Transit systems, Taipei City Government. pp. 225-249 (2002)

19. Lin, X. L., "The Practical Investigation of Interfaces in MRTS," reports of technological transfer of MRTS systems (1997).

20. Lock, D., Project Management, Brookfield, Vt., Gower, Hampshire, U.K. (1996).

21. Love, S, "Subcontractor Partnering: I'll Believe It When I See It," Journal of Management in Engineering, SEP/OCT, Feature, pp. 29-31 (1997).

22. Moore, C., Mosley, D. and Slagle, M. "Partnering Guidelines Fir Win-Win Project Management," Proj. Manage. J., Vol. 22, No. 1, pp. 18-21 (1992)

23. Morris, P. W. G., "Managing Project Interfaces-Key Points for Project Success," Project Management Handbook, D. I. Cleland, and W. R. King, eds., Van Nostrand Reinhold, New York (1983).

24. Norusis, M. J., "SPSS for Windows, Professional Statistics, Release 6.0." Statistical Package for Social Science, Inc., Chicago (1933).

25. Patrick, H. P., "Interface," Project Management: Getting the Job Done on Time and in Budget," Butterworth-Heinemann, Newton, Mass (1997).

26. Pavitt, T. C and Gibb, A. G. F., "Interface Management within Construction: in Particular, Building Façade," J. Constr. Eng. Manage., ASCE, Vol. 129, No. 1 (2003)

27. Pe, W. Z., "Integration Management of Interface in MRTS Construction Project," Semi-Annual journal of MRTS Technology, No. 23, pp. 223-236 (2000).

28. Stuckenbruck, L. C. "Project Integration in the Matrix Organization," Project Management Handbook, Van Nostrand Reinhold, New York, pp. 3758 (1983).

29. Tirella, O. C and Bates, G. D, Win-Win Negotiating: A Professional's Playbook, American Society of Civil Engineers, New York (1993).

30. Walker, D. H. T., "Choosing an Appropriate Research Methodology," Constr. Manage. Eco., Vol. 15, No. 2, pp. 149-159 (1997).

31. Wang, M. D. et al., "The Application of Management System within Involved Parties in the Construction Site," Construction Management Association of the Republic of China (1996).

32. Wu, Y., "Basic Requirement and Construction Interface of Escalator Equipment in MRTS Systems," Semi-Annual Journal of MRTS Technology, No. 24, pp. 245-264 (2001).

33. Ye, H. A, , "Improvement for Interface Management of Construction," First Construction Management Academic Conference, pp. 281-289 (1999). 